Review

\title{
Obesity and cancer: the role of adipose tissue and adipo-cytokines-induced chronic inflammation
}

\author{
Rosa Divella $^{1 凶}$, Raffaele De Luca ${ }^{2}$, Ines Abbate ${ }^{1}$, Emanuele Naglieri $^{3}$, Antonella Daniele ${ }^{1}$ \\ 1. Clinical Pathology Laboratory, Department of Experimental Oncology. Giovanni Paolo II National Cancer Institute, V.Le Orazio Flacco 65, 70124 -Bari, Italy. \\ 2. Department of Surgery Oncology. Giovanni Paolo II National Cancer Institute, V.Le Orazio Flacco 65, 70124 -Bari, Italy. \\ 3. Department of Medical Oncology, Giovanni Paolo II National Cancer Institute, V.Le Orazio Flacco 65, 70124 -Bari, Italy. \\ $\square$ Corresponding author: Rosa Divella, Ph.D., Department of Experimental Oncology, Clinical Pathology Laboratory National Cancer Institute Giovanni Paolo
} II, Viale Orazio Flacco, 65, 70100 - Bari, Italy. Tel. +39 805555259; E-mail: rosadive@inwind.it.

() Ivyspring International Publisher. Reproduction is permitted for personal, noncommercial use, provided that the article is in whole, unmodified, and properly cited. See http://ivyspring.com/terms for terms and conditions.

Received: 2016.07.18; Accepted: 2016.09.19; Published: 2016.11.26

\begin{abstract}
Adipose tissue in addition to its ability to keep lipids is now recognized as a real organ with both metabolic and endocrine functions. Recent studies demonstrated that in obese animals is established a status of adipocyte hypoxia and in this hypoxic state interaction between adipocytes and stromal vascular cells contribute to tumor development and progression. In several tumors such as breast, colon, liver and prostate, obesity represents a poor predictor of clinical outcomes. Dysfunctional adipose tissue in obesity releases a disturbed profile of adipokines with elevated levels of pro-inflammatory factors and a consequent alteration of key signaling mediators which may be an active local player in establishing the peritumoral environment promoting tumor growth and progression. Therefore, adipose tissue hypoxia might contribute to cancer risk in the obese population. To date the precise mechanisms behind this obesity-cancer link is not yet fully understood. In the light of information provided in this review that aims to identify the key mechanisms underlying the link between obesity and cancer we support that inflammatory state specific of obesity may be important in obesity-cancer link.
\end{abstract}

Key words: adipocytes inflammation, adipocytokine, obesity, cancer.

\section{Introduction}

Obesity, defined as abnormal excess accumulation of fat in adipose tissue, is a chronic low-grade inflammation. It is associated with a high risk of developing type 2 diabetes, metabolic syndrome cardiovascular disease, and several types of cancer [1-5]. In tumors of breast, colon, liver and prostate, obesity represents a poor predictor of clinical outcomes. [6-9]. The precise mechanisms underlying this obesity-cancer link are not yet well understood. The definition of overweight and obesity according to WHO is defined by body mass index (BMI, weight/height $\mathrm{m}^{2}$ ): $\mathrm{BMI}=25-29 \mathrm{~kg} / \mathrm{m}^{2}$ for overweight and BMI $\geq 30 \mathrm{~kg} / \mathrm{m}^{2}$ for obesity, Table 1 [10]. The adipose tissue in addition to its ability to keep lipids is now recognized as a real organ with both metabolic and endocrine functions [11]. The knowledge about the structural and functional

principles of adipose tissue has evolved considerably over the last ten years to get to today's conception of the adipose organ [12,13]. At the cellular level it shows considerable heterogeneity, being constituted only half from mature adipocytes, and for the rest from preadipocytes, fibroblasts, endothelial cells, nerve cells and macrophages $[14,15]$. (Figure 1). The adipose tissue is divided in brown adipose (BAT) and in white adipose (WAT). The BAT is only a minimal part of the body, which in an adult is approximately 50 grams compared to kilograms of the white adipose tissue. The most important knowledge we have today on the white adipose tissue regarding its role. Recently several studies have clearly demonstrated that the white adipose tissue is a true endocrine organ, a secretory organ metabolically active, and far from being inert tissue [16,17]. It consists of different 
cell types and produces a number of adipokines and cytokines [18]. Both stem cells (one every 50 adipocytes) that the pre-adipocytes are found in adipose tissue. These cells, when stimulated and activated, have the capacity to divide and give rise to new adipocytes. Once formed, the new white adipocytes will remain so until the death of the individual: they can then increase or decrease in volume but not in number [19]. It is therefore important to prevent an excessive increase of adipose tissue and the number of adipocytes, especially in children, in which this phenomenon would condemn them, with high probability, to remain obese for the rest of life [20].

Table 1 Diagnostic criteria for obesity in according to WHO classification.

\begin{tabular}{ll}
\hline Category & $\begin{array}{l}\text { BMI value } \\
(\mathrm{kg} / \mathrm{mq})\end{array}$ \\
\hline Underweight & $\leq 18.5$ \\
Normal Weight & $18.5-24.9$ \\
Overweight & $25-29.9$ \\
Obesity Type 1 & $30-34.9$ \\
Obesity Type 2 & $\geq 35$ \\
\hline
\end{tabular}

\section{Adipocytes: hypertrophy and hyperplasia}

Body fat is stored in white adipose tissue into smaller fat cells, adipocytes, whose number and size varies greatly from individual to individual. Adipocytes, to ascertaining which of lipids, vary their size (diameter 20-200 $\mu \mathrm{m}$ ): they are able changing of 20 times their diameter and out several thousand times their volume. Adipocytes modulate a variety of physiological responses which include the metabolism of lipids and glucose, inflammation, blood pressure and ultimately angiogenesis and homeostasis [21]. Body fat may increase in two ways

\section{Lean adipose tissue}

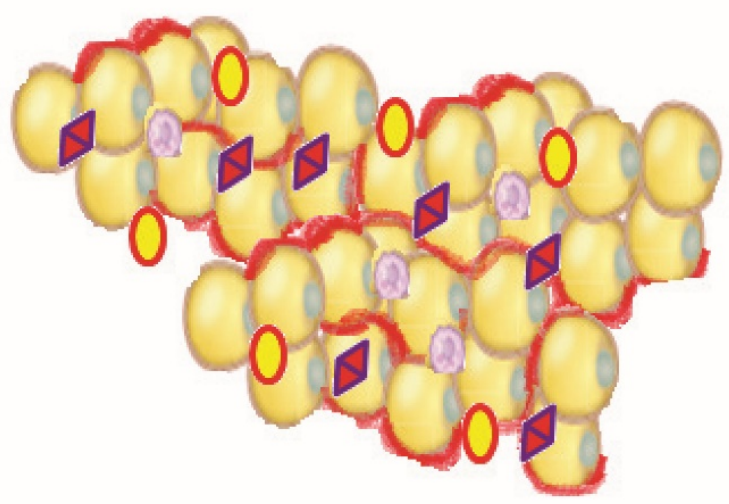

(Figure 2):

- Hypertrophy: increase in the volume of adipocytes

- Hyperplasia: increase in the number of adipocytes

The hyperplasia of adipose tissue occurs during certain periods of life (last half of pregnancy, the first year of life and the beginning of puberty) or in special situations, such as obesity. In all other cases remain the phenomena of hypertrophy $[22,23]$. It is important to remember that the hyperplasia, unlike hypertrophy, is an irreversible process, so even in the event of slimming exasperated cells does not decrease in number but, only in their volume [24]. When an obese person slimming, fat cells lose a certain amount of fat, reducing their volume, but the number of adipocytes cannot be reduced. That's the reason a person with obesity regained in the short term much of body fat lost when suspending the crash diet. An excessive accumulation of triglyceride inside white adipocytes causes a progressive increase of their volume. The adipocyte hypertrophy creates the risk of compromising the integrity of the adipocytes themselves who do not have unlimited power to increase the volume; therefore reached a certain limit an adipocyte excessively hypertrophic undergoes events of hypoxia and necrosis [25]

As a result there has been an alteration of adipose tissue with changing in the production of steroid hormones and adipokines, development of metabolic disorders, and the onset of chronic subclinical inflammation $[26,27]$. These alterations are implicated in the mechanism of carcinogenesis, progression and tumor metastasis [28] (Figure 3). Recent studies demonstrated that in obese animals is established a status of adipocyte hypoxia and in this hypoxic state interaction between adipocytes and stromal vascular cells contribute to tumor development and progression [29]. In obesity, adipose tissue hypoxia may cause cellular mechanisms that lead to the Macrophage development of insulin resistance, to a state of chronic Fibroblasts inflammation with infiltration of macrophages, the reduction of adiponectin and increased of Preadipocyte leptin, adipocyte death, ER stress and mitochondrial dysfunction [30-34]. Therefore, Adipocyte adipose tissue hypoxia might contribute to cancer risk in the

Capillary obese population $[35,36]$. Hypoxia-inducible factor 1 alpha (HIF-1a), is an important

Figure 1 Schematic representation of adipose tissue. 
transcription factor that is regulated by hypoxia and in tumors leads to increased vascularization. HIF-1a is involved in the regulation of transcription of genes implicated in the mechanisms of carcinogenesis. These include angiogenesis, cell survival, invasion and metabolism of glucose. Finally, HIF-1a was associated with an increase occurrence of metastases. Furthermore HIF-1a inhibition might improve sensitivity of tumors to radiation $[37,41]$.

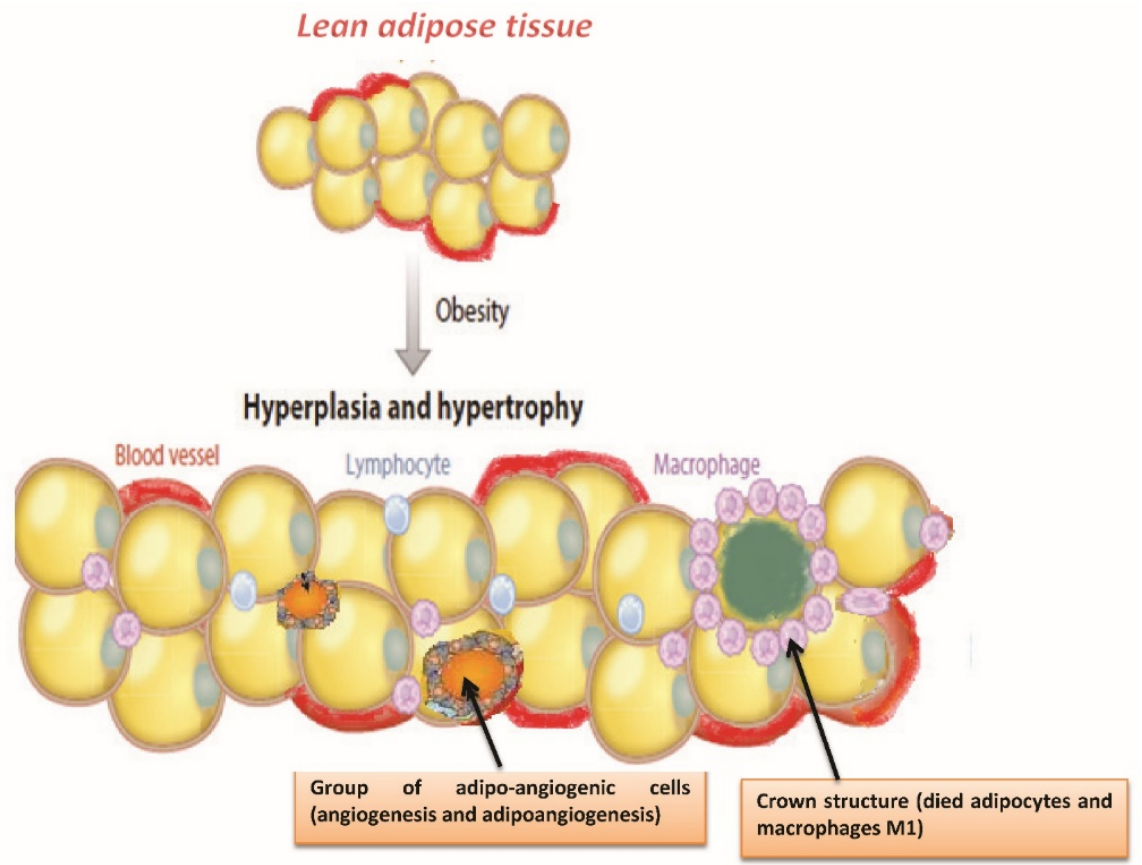

Figure 2 Adipocyte hypertrophy and hyperplasia induces an inflammatory cascade and accumulation of immune cells, activation of leukocytes, endothelial cells coupled with angiogenesis, adipogenesis and death of adipocytes.

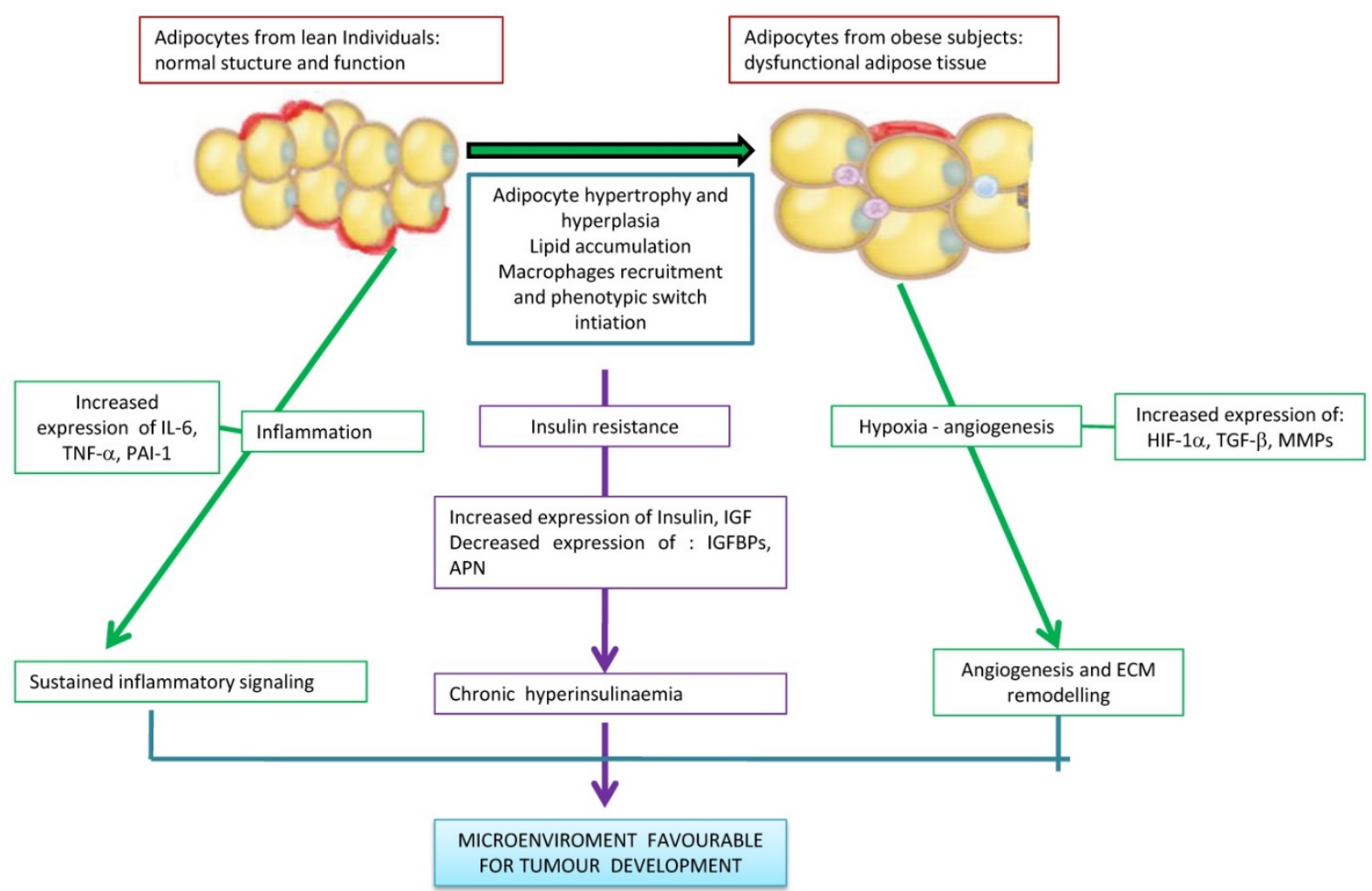

Figure 3 The different mechanisms linking obesity and cancer. Excessive adipose tissue is related to the changes of the lipids concentrations in the circulation, levels of species reactive oxygen as well as to secretion of adipokines and circulating hormones. The hypertrophy and hypoxia of adipose tissue cause chronic inflammation. Thus, cytokines secreted by inflamed adipose tissue, production of angiogenic factors, infiltration of macrophages MI and insulin resistance associated with obesity may favor stimulation of a favorable microenvironment for tumorigenesis. 
To block hypertrophy, each fat cell realizes two actions [42,43]:

- amends its protein synthesis by producing and secreting cytokines, inflammatory proteins and hormones which are able to prevent further entry of fatty acids on the inside;

- stimulates the increase of the number of new adipocytes in order to accumulate triglycerides that are continuously introduced with the daily nutrition.

\section{Adipocytokines}

The white adipocytes produce and secrete a large number of molecules, collectively called adipocytokines or adipokines. The adipocytes have a robust protein synthesis capable of producing specific proteins in norm-volume condition, but in the presence of hypertrophy undergo a change in their protein synthesis, with production of inflammatory proteins (cytokines) [44-46]. While the majority of adipokines, such as tumor necrosis factor- $\alpha$, IL-6, PAI-1 are pro-inflammatory, adiponectin on the contrary is an adipokine with anti-inflammatory, anti-diabetic, cardio protective and anti-tumor actions $[47,49]$. Dysfunctional adipose tissue in obesity releases a disturbed profile of adipokines with elevated levels of pro-inflammatory factors and reduced adiponectin [50]. (Figure 4)

This variation in the pathophysiology of adipocytes is the key to understanding the relationship between obesity, insulin resistance status, metabolic syndrome, diabetes mellitus type 2, atherosclerosis and several types of cancer (breast, prostate, colon, liver) [51-54].

However, it acquired the close relationship between the production of inflammatory proteins and the degree of hypertrophy of adipocytes $[55,56]$.

Follows is a summary of the various proteins secreted by adipocytes both in conditions of normal volume and in hypertrophic adipocyte (Figure 5):

- Cytokines: TNF-a, IL-1, IL-6, IL-10.

- Transforming Growth Factor- b (TGF-b).

- Leptin, resistin, adiponectin.

- Monocyte Chemoattractive Protein-1 (MCP-1).

- CXCL5

- Haemostatic Proteins: Plasminogen Activator Inhibitor-1 (PAI-1)

- Proteins involved in blood pressure regulation: angiotensinogen.

- Angiogenic proteins: vascular endothelial growth factor (VEGF).

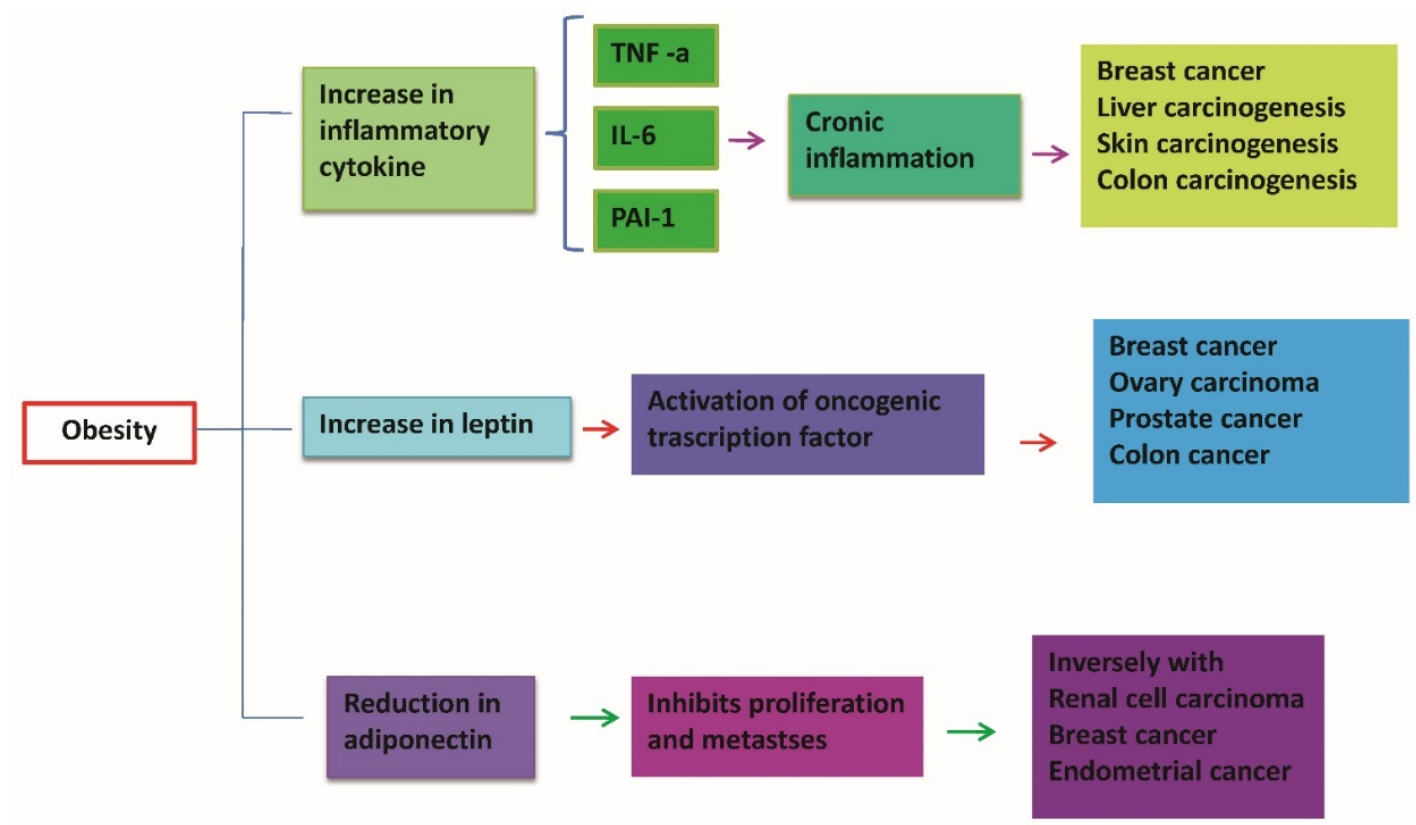

Figure 4 Dysfunctional adipose tissue in obesity is associated with disturbed profile of mediators released from this tissue establishing a state of chronic inflammation. An increase of pro-inflammatory cytokines and leptin causes a down regulation of adiponectin. This results in a reduction of anti-inflammatory and anti-tumor activity explicated by adiponectin. In obesity high levels of pro-inflammatory cytokines such as TNF- $\alpha$ and IL-6 act systematically and could induce oncogenic effects in distant sites such as colon, liver, breast. 


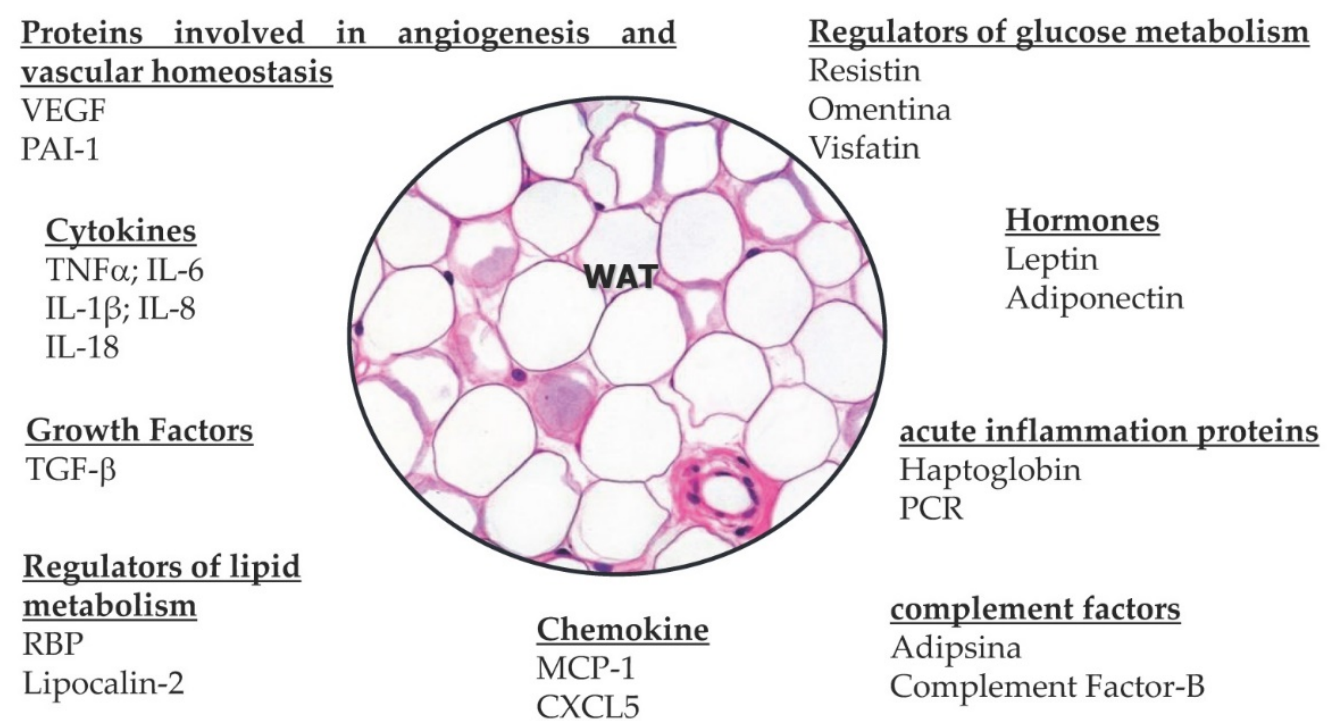

Figure 5 Summary of the various proteins secreted by white adipocytes both in conditions of normal volume and in hypertrophic adipocytes. Adipose tissue play an active role in controlling the physiological and pathological process through various adipokines. Dysfunctional adipose tissue in obesity releases a disturbed profile of adipokines with elevated levels of pro-inflammatory factors like leptin, IL-6 and TNF-alfa and reduced adiponectin that is protective against tumourigenesis. These adipokines have been implicated in cancer development and progression through their effects on insulin resistance, lipolysis and various inflammatory pathways. In the context of obesity, the hypertrophic expansion of adipose tissue induces local hypoxia, inflammatory activation and reactive angiogenesis, changes which favour tumourigenesis.

The adipokines constitute a class of proteins extremely heterogeneous, both in structural and functional terms, but have some common characteristics. From the functional viewpoint adipokines are polyvalent molecules, involved in a large number of physiological and pathological processes in fact modulate the sensitivity of peripheral tissues to insulin, regulate appetite, energy expenditure, and glucose and lipids metabolism, homeostasis, angiogenesis, blood pressure and all the axis of endocrine and reproductive systems [57-59]. In addition, many appear to be strongly related to immunity and inflammation $[60,61]$. Within this wide range of signals and protein factors, it is evident how the white adipose tissue plays an active role in controlling the physiological and pathological processes, in particular the metabolism and energy homeostasis $[62,63]$. It is precisely through the various adipokines that the white adipose tissue communicates directly with the peripheral tissues and in particular with the skeletal muscle. And above all there is an intense cross-talk between white adipocytes and brain through leptin and the sympathetic nervous system [64-66]. Following describes the two best-known hormones secreted by white adipocytes: adiponectin and leptin.

Adiponectin is the main hormone produced by mature not hypertrophic white adipocytes. It carries a powerful anti-inflammatory action, in addition to its role in modulating insulin sensitivity improving it in the liver, muscle and adipocytes $[67,68]$. Increase the oxidation of lipids in tissues by promoting weight loss, improves endothelium-dependent vasodilatetion, reduces the production of oxygen free radicals, has anti-inflammatory action: reduces the expression of adhesion proteins, the production of TNF-alpha and counteracts the effects on endothelial function, inhibits the differentiation of monocytes into macrophages, inhibits the activity of metalloproteases wall, inhibits the effects of LDL (low density lipoprotein) oxidized on endothelial cells of the capillaries of the microcirculation content in 'adipose organ and systemic vascular network [69,70]. Plasma levels of adiponectin are reduced in obesity in the abdomen, in the male, in postmenopausal women, in high blood pressure, hypertriglyceridemia in type 2 diabetes mellitus and coronary artery disease [71-77]. Adiponectin expression is decreased by TNF-a and IL-6, increased by PPARy agonists [78] (Figure 6). Adiponectin exerts a reduction in the proliferation of adipocyte cells, endothelial cells and tumor cells $[79,80]$. In addition to inhibit tumor growth and survival, adiponectin blocks angiogenesis by decreasing the expression of VEGF and Bcl-2 (anti-apoptotic) and increasing the activity of p53, Bax and caspase (pro-apoptotic), with resulting in apoptosis of endothelial cells. Likewise, adiponectin was shown to reduce TNF- $\alpha$ induced effects on cell proliferation and migration [81,82]. In fact, it has been shown that the reduced concentrations of adiponectin observed in obesity may represent one of the mechanisms that connect obesity with the development and progression of cancer [83-86]. importantly, adiponectin levels are decreased in 
obesity-associated insulin resistance and cancer [87]. Insulin resistance is increased, with resultant elevation in insulin and bioavalible IGF1 levels, which enhance tumor cellular proliferation $[88,89]$. Low levels of adiponectin exert pro-inflammatory effects by means of the rise of the production of various proinflammatory cytokines including TNF- $\alpha$ and IL-6, favoring in this manner the onset of a permissive tumor microenvironment facilitating tumor promotion [90-92]. In several studies has been observed a negative correlation between circulating adiponectin levels and the risk of developing certain types of cancer such as colorectal, breast, pancreatic, liver and prostate cancer [93-96]. Low adiponectin levels are potentially associated with carcinogenesis [97-99]. The adiponectin protective effects in tumors also include the inhibition of leptin proliferative signaling and inducing cell apoptosis [100-101].

Leptin is produced by white "normal" adipocytes and hypertrophic adipocytes, acts as a key mediator in body weight regulation [102]. Once entered into the blood stream, reach the brain, where it provides a critical hormonal signal to the hypothalamus in the regulation of appetite and energy expenditure: inhibition of appetite [103]. The production of this hormone is closely related to adipose tissue mass and volume of adipocytes: an increase in body fat, especially visceral fat, as well as a diet high in calories is associated with an increase in circulating levels of leptin where weight loss results in a reduction of the same $[104,105]$. The production of leptin is to limit the continuous entry of fatty acids in adipocyte hypertrophic, choice of defense needed to prevent cell death by excessive volume. Under conditions of obesity can develop a state of leptin resistance and therefore the actions ensured by this adipocyte hormone cannot be exercised $[106,107]$ (Figure 7). Leptin is currently at the centre of the obesity-cancer link, as it is produced in proportion to fat mass and potently induces cell mitogenesis, growth and motility [108-110]. Mature adipocytes secrete both adiponectin and leptin with preadipocytes showing a primarily secretion of high leptin levels [110-112]. An increase of preadipocyte pool in obese subjects is related to an increase in leptin levels, with proangiogenic and promitogenic properties [113,114]. Simultaneously, high levels of leptin leads other inflammatory cells stimulating the differentiation of monocytes into macrophages favoring in this manner the state of chronic inflammation obesity-associated [115]. In summary, leptin has an important role in the development of a large variety of malignancies increasing the expression of anti-apoptotic proteins, inflammatory markers (TNF-a, IL-6), angiogenic factors (VEGF), and also the hypoxia-inducible factor-1a (HIF-1a) $[116,117]$. These processes promote cancer cell survival, proliferation and migration $[118,119]$.

The activation of the inflammatory process occurs in the case of hypoxia or when the availability of oxygen is not adequate to the demands of white and brown adipose tissue. This results in a decrease in oxygen tension that activates the transcription factor HIF-1 (Hypoxia Inducible Factor-1) and generates a number of negative effects [120]:

- Inhibition of adiponectin production by white adipocytes;

- Induce a state of insulin resistance;

- Ischemia and necrosis of white adipocytes;

- The production of angiogenic factors;

- The release of inflammatory cytokines;

- Increased production of free radicals can also damage the DNA of the same adipocytes.

In conclusion, hypoxia of adipocytes is the key link between the initial cell damage and activation of the inflammatory process [121,122].

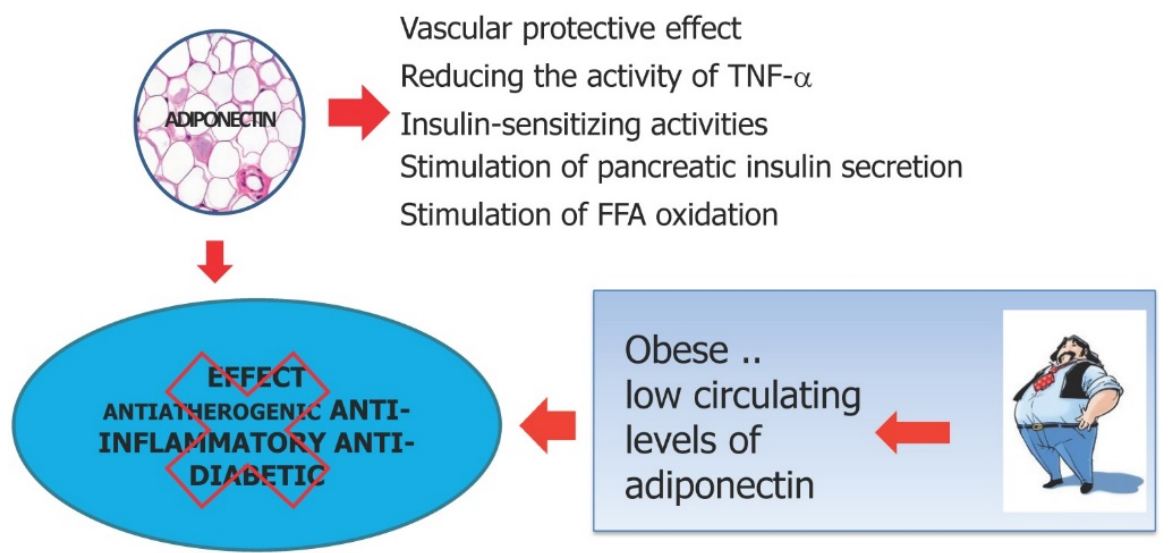

Figure 6 In obese subjects lower adiponectin levels lead to a reduction of the anti-inflammatory antidiabetic and antitumor power explicate by adiponectin. Decreased levels of adiponectin leads to a state of insulin resistance by cytokine-mediated inflammation contributing to the tumor permissive microenvironment that facilitates tumourigenesis. 

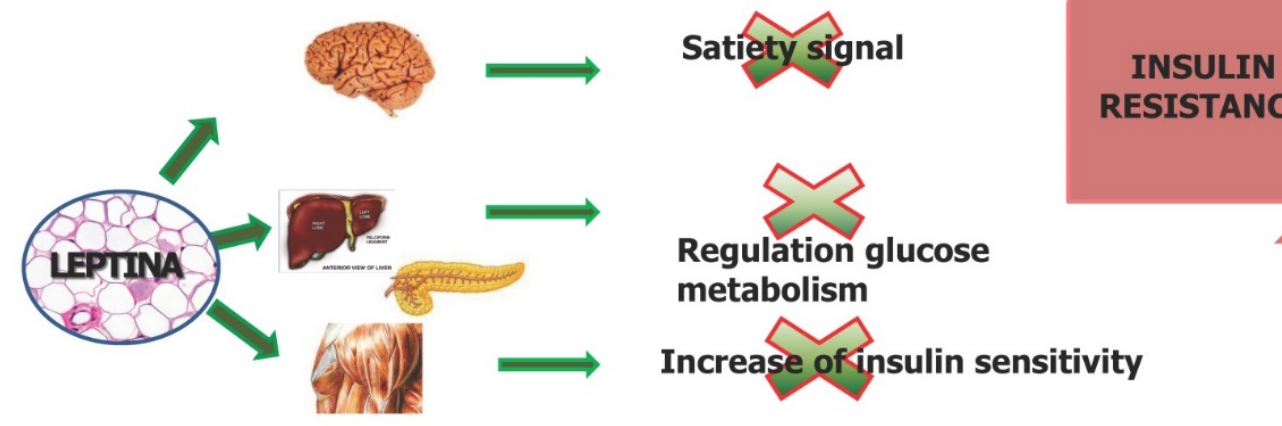

RESISTANCE
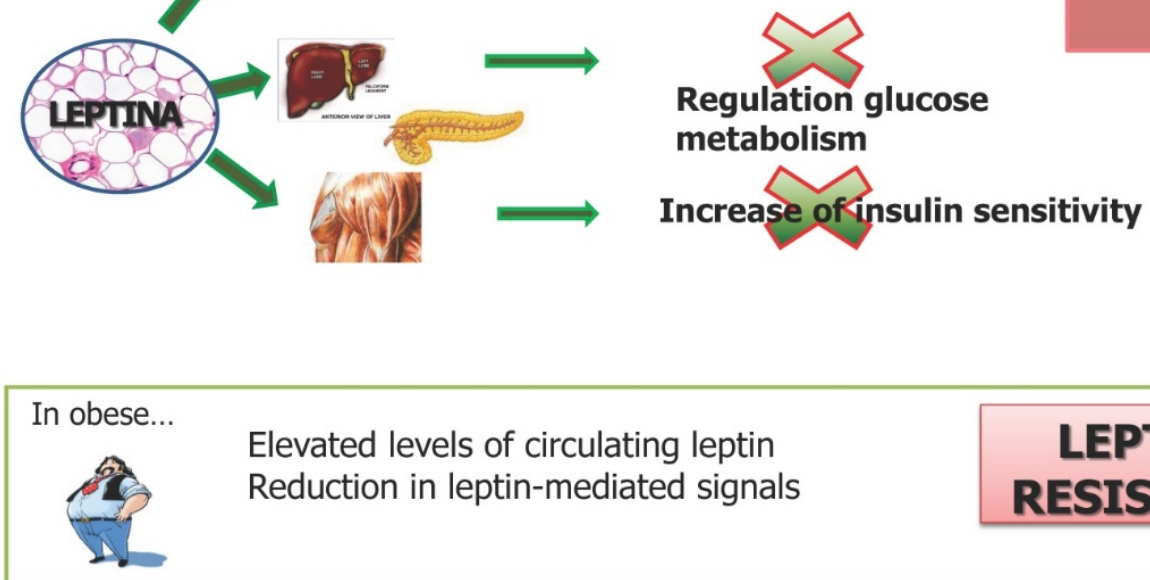

Elevated levels of circulating leptin

Reduction in leptin-mediated signals

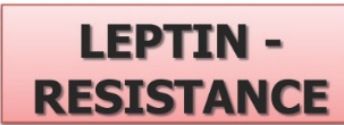

Figure 7 Leptin plays important action in regulating glucose metabolism, in the satiety signal and increase insulin sensitivity. Under conditions of obesity can develop a state of leptin resistance and therefore the actions ensured by this hormone cannot be exercised. In obese subjects an increase of adipocytes is related to an increase in leptin levels that activates inflammatory cell response and induces pro-inflammatory cytokine production maintaining the obesity-associated state of chronic inflammation. In this context increased leptin levels lead to increased expression of anti-apoptotic, pro-inflammatory and angiogenic factors that promote proliferation and migration of cancer cells.

\section{White adipocytes and inflammation: the inflammatory Triad}

The hypertrophic hypoxic white adipocytes present alteration of the extracellular matrix and collagen. In this condition activating their capacity to adapt to aggressive situations, changing their natural protein synthesis and directing the production of their proteins to cytokines, inflammatory proteins damaging cells and entire systems anatomy of the body [123]. Hypertrophy associated with subsequent hypoxia, is therefore the functional transition to generate a "change" of protein synthesis to local and systemic inflammatory agents [124]. There is an axis between white hypertrophic adipocytes secreting inflammatory proteins and functional status of the endothelium of the capillaries and systemic fat [125]. The inflammatory proteins secreted by hypertrophic and hypoxic white adipocytes are the primary cause of atherosclerosis, state of insulin resistance, high blood pressure, type 2 diabetes mellitus, metabolic syndrome, bone joint and muscle tendon degeneration [126-128]. Furthermore links between obesity and inflammation and between chronic inflammation and cancer may suggest that inflammation may be important in linking obesity to cancer [129-132]. Virchow over 100 years ago, emphasized the link between chronic inflammation and cancer development. He observed the increased presence of leukocytes in neoplastic tissue [133,134]. Since then, the role of chronic inflammation has been observed in multiple cancer types. Like adipose tissue, tumor microenvironment is composed of multiple cell types including epithelial cells, fibroblasts, mast cells, and cells of the innate and adaptive immune system that favors a pro-inflammatory and pro-tumorigenic environment $[135,136]$.

Belong to the group of inflammatory cytokines:

- Tumor Necrosis Factor-alpha (TNF-a)

- Interleukin-1 (IL-1)

- Interleukin-6 (IL-6)

which constitute a "triad inflammatory" that acts in adipose tissue and of all the other cells of the whole organism [137]. Obesity causes chronic inflammation silent that is without symptoms, in charge of related diseases with functional and aesthetic decay of the whole organism [138]. The triad inflammatory (TNF-a, IL-1, IL-6) shall set up actions aimed at integrity adipocyte hypertrophy and hypoxic in the organ fat and aggressive actions whole body level with inflammatory degenerative diseases $[139,140]$.

Tumor necrosis factor-a. Another pro-inflammatory cytokine secreted by adipocytes is TNF- $\alpha$, increased secretion of this cytokine is found in obese subjects [141]. More than two decades ago TNF-a was first described as a cytokine with antitumor properties but later when its antitumor activity was tested on cancer patients became apparent its active role in promoting cancer [142]. Thereafter has been observed that the proinflammatory role of TNF-a becomes involved in 
all stages of tumorigenesis that include tumor cell transformation, survival, proliferation, invasion, angiogenesis and metastasis [143]. Animal models have shown a positive relationship between TNF- $\alpha$ and tumor development and progression in liver and colorectal cancer with elevated circulating concentrations in different tumor types [144-146]. In addition, TNF-a is not only produced by a wide variety of tumor cells but also by adipocytes. Levels of TNF- $\alpha$ are increased in obesity, indicating a role for this cytokine in the obesity-associated inflammation and particularly in insulin resistance and diabetes $[147,148]$.

Interleukin-6 Another cytokine produced by adipose tissue belonging to the group of pro-inflammatory cytokines is IL-6 whose levels are increased in obese subjects [149,150]. IL-6 is a key modulator in inflammation-associated carcinogenesis, regulates the expression of genes involved in the different steps of tumor growth and progression via the JAK/STAT signaling pathway $[151,152]$. In fact a relationship between IL-6 and carcinogenesis has been shown for several types of cancer and elevated circulating level correlate with disease aggressiveness and poor prognosis [153-157].

Interleukin-1 Interleukin-1 is a regulatory cytokine expressed in both normal tissues and in tumor cells. IL-1 can lead to the activation of transcription factors such as NF-kB and AP-1, and promote the expression and promote the expression of genes that regulate the mechanisms of survival, proliferation and tumor angiogenesis [158]. In obesity-related inflammation, IL-1 over-regulates HIF-1a protein through a classical NF-kB/COX-2 inflammatory signaling pathway culminating in up-expression of the angiogenic factor VEGF needed for tumor growth and metastasis [159].

The following summarizes the actions of inflammatory triad:

1. Reduction and block of capillaries lipoprotein lipase synthesis. The reduction and the absence of this enzyme on the wall of the capillaries in the adipose organ prevents the release of triglycerides from circulating VLDL in the blood, and then the non-entry of fatty acids into adipocytes; the value of triglycerides and cholesterol in the blood increases $[160,161]$.

2. Blocking of insulin receptors of adipocytes. This block implies a state of insulin resistance initially in the fat organ, subsequently of the whole body, particularly in muscles with increased glucose and insulin in the blood until the onset of diabetes mellitus type 2 [162-163].

3. Activation of lipoprotein lipase hormone sensitive in adipocytes with breakdown of triglycerides accumulated in hypertrophic white adipocyte, output of free fatty acids (FFA) with a consequent reduction in volume. Excess of FFA in the blood cause fatty liver and insulin resistance in the muscles, increasing glucose and insulin in the blood until the onset of diabetes mellitus type 2 [164].

4. Endothelial Inflammation. Exists an axis between hypertrophic and hypoxic white adipocytes secreting inflammatory proteins and functional status of capillaries endothelium of the adipose organ tissue and systemic vascular with the entire systemic vascular network (atherosclerosis and vein diseases) $[165,166]$. (Figure 8)
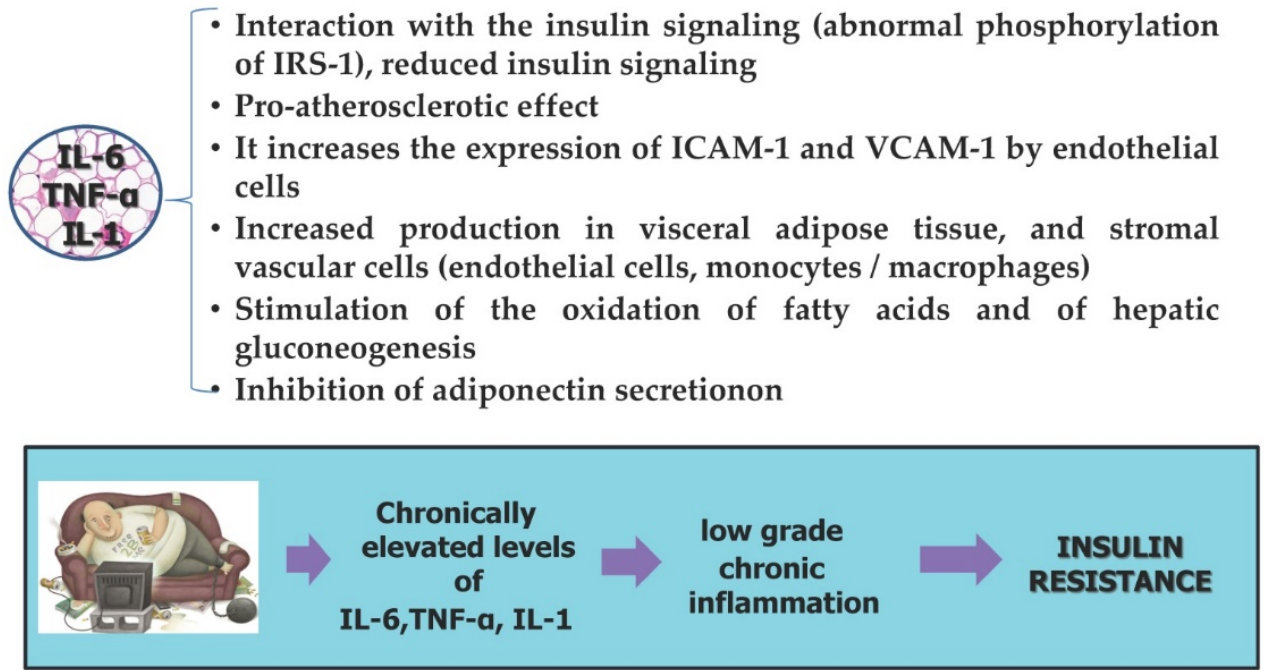

Figure 8 Actions of inflammatory triad. Obesity causes chronic silent inflammation with subsequent increased secretion of inflammatory triad cytokines and decreased production of adiponectin that make unable adipose tissue to store the surplus of free fatty acids contributing to a development of insulin resistance, type 2 diabetes, and obesity-related cardiovascular disease. The mitogenic and anti-apoptotic environment caused by elevated levels of insulin in obesity accelerates the stepwise accumulation of mutations and, hence, favor carcinogenesis. TNF-a, IL-6 and IL-1 signaling, enhancing carcinogenesis by increasing cell proliferation and neoangiogenic cell properties. In addition, the inflammatory enhancing expression of VEGF, ICAM-1 and VCAM-1 by endothelial cells. 


\section{Adipocytes, inflammation and insulin resistance}

One of obesity-related diseases is insulin resistance considered a major risk factor for cancer development and has been associated with poor prognosis for several cancers $[167,168]$.

The hypoxic hypertrophic adipocytes and macrophages in addition to an increase of the production of inflammatory cytokines TNF-a, IL-1, IL-6 also reduce the production of adipocyte hormones protective, including adiponectin $[169,170]$. The whole of these pathological changes leading to the appearance of a state of insulin resistance, which is established through different mechanisms still only partly elucidated:

- direct mechanism that includes the deactivation of the substrate of the insulin receptor (ISR-1) by phosphorylation of serine and threonine residues by inflammatory mediators such as IL- 6 and TNF-a [171];

- Indirect mechanism caused by the increase in free fatty acids (FFA) in the circulation, which cause an increase of other mediators of inflammation (e.g. NF-KB), implicated in insulin resistance $[172,173]$.

The insulin resistance is a condition characterized by not active insulin that is due to reduction of the receptors located in the cell membranes of adipose tissue and muscle, with an increase of blood glucose and insulin [174,175]. The defect of insulin action makes the fatty tissue less able to store glucose and fatty acids and fatty tissue as a compensatory response seeks to expand further through hypertrophy, but mostly hyperplasia [176]. In patients with insulin resistance there is an increase in glucose and insulin levels due to a reduced sensitivity of tissues to insulin [177]. In chronic hyperinsulinaemia it is observed increased secretion of IGF-1 and a reduced production of binding proteins so it results a further increase in circulating levels of IGF [178]. Through the IGF receptor, IGF activates downstream signaling pathways that promote mitogenic and proangiogenetic pathways and inhibit apoptosis [179]. The insulin and adipokine cancer hypotheses overlap, since he insulin-resistant state is mediated, at least in part, by cytokine-mediated inflammation [180]. The cytokines promote the insulin resistance which in turn leads to a state of chronic low-grade inflammation of the adipose tissue by establishing a favorable microenvironment for tumor promotion $[181,182]$.

\section{White adipocytes: hypoxia, ischemia and oxidative stress}

The adipocyte hypertrophy generates obstruction of capillaries with hypoxia and ischemia both individual white adipocytes (hypertrophic and hypossic) that the brown adipocytes [183]. For hypoxia means a pathological condition caused by a lack of oxygen in the blood or in adipose tissue, while ischemia is a condition caused by an inadequate blood flow [184]. Hypertrophy of white adipocytes damages the microcirculation, the vascular network of the entire organ adipose creating conditions of obstruction and constriction of capillaries with endothelial damage in the white and brown adipose tissue [185,186]. Furthermore, the progressive hypertrophy of white adipocytes and the expansion of the white adipose tissue make the same adipocytes more away from the vascular network, with reduction of the volumes of oxygen available [187]. The adipose organ is a major consumer of oxygen and the condition of hypoxia/ischemia generates a greater state of oxidative stress, able to direct the white adipocytes hypertrophic/hypoxic and towards the secretion of inflammatory proteins and brown adipocytes towards a situation of dysfunction $[188,189]$. The brown adipocyte is much richer in capillaries and requires significant volumes of oxygen to ensure adequate oxidation of fatty acids and ensure proper body temperature [190]. A hypoxic condition in brown adipocytes promotes the reduction of thermo genesis, i.e. the production of heat, and oxidation of fatty acids, with sensation of cold and continuous weight gain because the fatty acids are deposited in white adipocytes [191-193]. Moreover, in conditions of hypoxia and ischemia the brown adipocytes produce significant amounts of reactive oxygen radicals (Radical Oxygen Species, ROS) that damage their mitochondrial functionality [194-196]. Hypoxia occurs when oxygen availability is not adequate to the demand of both white and brown adipose tissue [197]. This results in a decrease in oxygen tension that activates the transcription factor HIF-1 (Hypoxia Inducible Factor-1) and generates a series of negative effects:

- inhibition of production of adiponectin by white adipocytes;

- induction of a status of insulin resistance;

- ischemia and necrosis of white adipocytes;

- production and release of inflammatory cytokines and angiogenic factors;

- Increased production of free radicals which are able to also damage the DNA of the same adipocytes. 
In conclusion, hypoxia and ischemia of adipocytes are the key link between the initial cell damage and activation of the inflammatory process [198-207].

\section{Adipocytes and cancer}

Adipose tissue is composed by a heterogeneous cell population mostly represented by adipocytes. Other cellular components including endothelial cells, macrophages, pericytes and adipocytes progenitor cells [208,209]. In adipose tissue interaction between adipocytes and stromal vascular cells contribute to tumor development and progression. Some types of tumors such as breast develop in proximity of adipocytes and metastasize in an environment mainly dominated by adipocytes such as the abdominal cavity [210]. Growth and metastasis of these tumors reflect the important role of the numerous adipocytes present in the microenvironment for tumor maintenance progression [211,212]. Microenvironment within local adipose deposits clearly provides a tumor permissive niche for transformed, infiltrating cells. During cancer progression cancer associated adipocytes undergo considerable morphological and functional alterations acquiring a fibroblast-like phenotype $[213,215]$. This phenotypic change involves a loss of expression of adiponectin and leptin the markers of terminal adipocyte differentiation. As a result an increase in the secretion of pro-inflammatory cytokines such as IL-6, TNF- $\alpha$ and PAI-1 that create a favorable environment inducing tumor cells to acquire a phenotype with major invasiveness and aggressiveness [216-220]. Alterations of the signaling mechanisms of the key mediators in obesity could represent determining factors for the establishment of a peritumoral environment to promote the development and tumor progression. In the light of information provided in this review we support that inflammatory state specific of obesity may be important in obesity-cancer link. Nevertheless, the molecular basis of the interactions that exist between the key mediators of tumor cells and adipocytes, which promote the establishment of a permissive tumor microenvironment is still unclear.

\section{Conclusion}

The results led to the hypothesis that an unfavorable adipokines profile with a reduction of adipokines with anti-inflammatory or anti-tumor activity could provide a comprehensive insight into the understanding of the molecular mechanisms involved in carcinogenesis related to obesity. This can provide the specific targets that are involved in those mechanisms whereby obesity leads to tumor progression. In conclusion, in obese subjects may become useful to follow a path to preventing cancer and its progression reduction plan to stop the inflammatory cascade, improve insulin sensitivity and contrast the factors that induce hypoxia.

\section{Acknowledgement}

This work was supported by grants from Italian Ministry of Health "Ricerca Corrente" - 2013-2015 grant from Giovanni Paolo II National Cancer Institute, Bari, Italy.

\section{Conflict of interest}

None declared.

\section{References}

1. Hossain P, Kawar B, El Nahas M. Obesity and diabetes in the developing world - a growing challenge. N Engl J Med 2007; 356: 213-215.

2. Kent BD, McNicholas WT, Ryan S. Insulin resistance, glucose intolerance and diabetes mellitus in obstructive sleep apnoea. J Thorac Dis 2015; 7(8): 1343-1357.

3. Owen CG, Kapetanakis VV, Rudnicka AR, et al. Body mass index in early and middle adult life: prospective associations with myocardial infarction, stroke and diabetes over a 30-year period: the British Regional Heart Study. BMJ Open 2015; 5(9): e008105. doi: 10.1136/bmjopen-2015-008105.

4. van Kruijsdijk RC, van der Wall E, Visseren FL. Obesity and cancer: the role of dysfunctional adipose tissue. Cancer Epidemiol Biomark Prev 2009; 18: 2569-2578.

5. Flegal KM, Carroll MD, Kit BK, Ogden CL. Prevalence of obesity and trends in the distribution of body mass index among US adults, 1999- 2010. JAMA 2012; 307: 491-497.

6. Calle EE, Rodriguez C, Walker-Thurmond K, Thun MJ. Overweight, obesity, and mortality from cancer in a prospectively studied cohort of U.S. adults. N Engl J Med 2003; 348: 1625-1638.

7. Yoon HH, Lewis MA, Shi Q et al. Prognostic impact of body mass index stratified by smoking status in patients with esophageal adenocarcinoma. J Clin Oncol 2011; 29: 4561-4567.

8. Widschwendter P, Friedl TW, Schwentner L, et al. The influence of obesity on survival in early, high-risk breast cancer: results from the randomized SUCCESS A trial. Breast Cancer Res 2015; 17: 129.

9. Cantarutti A, Bonn SE, Adami HO, et al. Body mass index and mortality in men with prostate cancer. Prostate 2015; 75(11): 1129-1136.

10. Fletcher I. Defining an epidemic: the body mass index in British and US obesity research 1960-2000. Sociol Health Illn 2014; 36(3): 338-353.

11. Kershaw EE, Flier JS. Adipose tissue as an endocrine organ. J Clin Endocrinol Metab 2004; 89(6): 2548-2556.

12. Fischer-Posovszky P, Wabitsch M, Hochberg Z. Endocrinology of adipose tissue - an update. Horm Metab Res 2007; 39(5): 314-321.

13. Poulos SP, Hausman DB, Hausman GJ. The development and endocrine functions of adipose tissue. Mol Cell Endocrinol 2010; 323(1): 20-34.

14. Zhang Y, Bellows CF, Kolonin MG. Adipose tissue-derived progenitor cells and cancer. World J Stem Cells 2010; 2(5): 103-113.

15. Cristancho AG, Lazar MA. Forming functional fat: a growing understanding of adipocyte differentiation. Nat Rev Mol Cell Biol 2011; 12(11): 722-734.

16. Proença AR, Sertié RA, Oliveira AC, et al. New concepts in white adipose tissue physiology. Braz J Med Biol Res 2014; 47(3): 192-205.

17. Vázquez-Vela ME, Torres $\mathrm{N}$, Tovar AR. White adipose tissue as endocrine organ and its role in obesity. Arch Med Res 2008; 39(8): 715-728.

18. Esteve Ràfols M. Adipose tissue: cell heterogeneity and functional diversity. Endocrinol Nutr 2014; 61(2): 100-112.

19. Ali AT, Hochfeld WE, Myburgh R, Pepper MS. Adipocyte and adipogenesis. Eur Cell Biol 2013; 92(6-7): 229-236.

20. Simmonds M, Burch J, Llewellyn A, et al. The use of measures of obesity in childhood for predicting obesity and the development of obesity-related diseases in adulthood: a systematic review and meta-analysis. Health Technol Assess 2015; 19(43): 1-336.

21. Laforest S, Labrecque J, Michaud A, et al. Adipocyte size as a determinant of metabolic disease and adipose tissue dysfunction. Crit Rev Clin Lab Sci 2015; 18: 1-13.

22. Stupin JH, Arabin B. Overweight and Obesity before, during and after Pregnancy: Part 1: Pathophysiology, Molecular Biology and Epigenetic Consequences. Geburtshilfe Frauenheilkd 2014; 74(7): 639-645.

23. Bays H. Central obesity as a clinical marker of adiposopathy; increased visceral adiposity as a surrogate marker for global fat dysfunction. Curr Opin Endocrinol Diabetes Obes 2014; 21(5): 345-351. 
24. Parlee SD, Lentz SI, Mori $\mathrm{H}$, MacDougald OA. Quantifying size and number of adipocytes in adipose tissue. Methods Enzymol 2014; 537: 93-122.

25. Rosenow A, Noben JP, Bouwman FG, et al. Hypoxia-mimetic effects in the secretome of human preadipocytes and adipocytes. Biochim Biophys Acta 2013; 1834(12): 2761-2771.

26. Guilherme A, Virbasius JV, Puri V, Czech MP. Adipocyte dysfunctions linking obesity to insulin resistance and type 2 diabetes. Nat Rev Mol Cell Biol 2008; 9: 367-377.

27. Hursting SD, Digiovanni J, Dannenberg AJ, et al. Obesity, energy balance, and cancer: new opportunities for prevention. Cancer Prev Res 2012; 5: 1260-1272.

28. Nieman KM, Romero IL, Van Houten B, Lengyel E. Adipose tissue and adipocytes support tumorigenesis and metastasis. Biochim Biophys Acta 2013; 1831(10): 1533-1541.

29. Almendros I, Gileles-Hillel A, Khalyfa A, et al. Adipose tissue macrophage polarization by intermittent hypoxia in a mouse model of OSA: effect of tumor microenvironment. Cancer Lett 2015; 361(2):233-239.

30. Jiang $\mathrm{C}, \mathrm{Kim} \mathrm{JH}, \mathrm{Li} \mathrm{F}$, et al. Hypoxia-inducible factor 1a regulates a SOCS3-STAT3-adiponectin signal transduction pathway in adipocytes. J Biol Chem 2013; 288(6): 3844-3857.

31. Petrangeli E, Coroniti G, Brini AT, et al. Hypoxia Promotes the Inflammatory Response and Stemness Features in Visceral Fat Stem Cells from Obese Subjects. J Cell Physiol 2016; 231(3): 668-679.

32. Bays H. Central obesity as a clinical marker of adiposopathy; increased visceral adiposity as a surrogate marker for global fat dysfunction. Curr Opin Endocrinol Diabetes Obes 2014; 21(5): 345-351.

33. Lee YS, Kim JW, Osborne $\mathrm{O}$, et al. Increased adipocyte $\mathrm{O} 2$ consumption triggers HIF-1a, causing inflammation and insulin resistance in obesity. Cell 2014; 157(6): 1339-1352.

34. Trayhurn P. Hypoxia and adipocyte physiology: implications for adipose tissue dysfunction in obesity. Annu Rev Nutr 2014; 34: 207-236.

35. Pérez-Hernández AI, Catalán V, Gómez-Ambrosi J, et al. Mechanisms linking excess adiposity and carcinogenesis promotion. Front Endocrinol (Lausanne) $2014 ; 5: 65$.

36. Diedrich J, Gusky HC, Podgorski I. Adipose tissue dysfunction and its effects on tumor metabolism. Horm Mol Biol Clin Investig 2015; 21(1): 17-41.

37. Matafome P, Santos-Silva D, Sena CM, Seiça R. Common mechanisms of dysfunctional adipose tissue and obesity-related cancers. Diabetes Metab Res Rev 2013; 29(4): 285-295.

38. Yamada S, Utsunomiya T, Morine $Y$, et al. Expressions of hypoxia-inducible factor-1 and epithelial cell adhesion molecule are linked with aggressive local recurrence of hepatocellular carcinoma after radiofrequency ablation therapy. Ann Surg Oncol 2014; 21 Suppl 3: S436-442

39. Tsai $\mathrm{YP}, \mathrm{Wu} \mathrm{KJ}$. Hypoxia-regulated target genes implicated in tumor metastasis. J Biomed Sci 2012; 19: 102

40. Kizaka-Kondoh S, Kuchimaru T, Kadonosono T. Pathophysiological response to hypoxia - from the molecular mechanisms of malady to drug discovery: hypoxia-inducible factor-1 (HIF-1)-active cells as a target for cancer therapy. J Pharmacol Sci 2011; 115(4): 440-445.

41. Nagasawa H. Pathophysiological response to hypoxia - from the molecular mechanisms of malady to drug discovery: drug discovery for targeting the tumor microenvironment. J Pharmacol Sci 2011; 115(4): 446-452

42. Wensveen FM, Valentić S, Šestan M, et al. The "Big Bang" in obese fat: Events initiating obesity-induced adipose tissue inflammation. Eur J Immunol 2015; 45(9): 2446-2456

43. Huh JY, Park YJ, Ham M, Kim JB. Crosstalk between adipocytes and immune cells in adipose tissue inflammation and metabolic dysregulation in obesity. Mol Cells 2014; 37(5): 365-371.

44. de Heredia FP, Gómez-Martínez S, Marcos A. Obesity, inflammation and the immune system. Proc Nutr Soc 2012; 71(2): 332-338.

45. Balistreri CR, Caruso C, Candore G. The role of adipose tissue and adipokines in obesity-related inflammatory diseases. Mediators Inflamm 2010; 2010:802078. doi: 10.1155/2010/802078.

46. Ouchi N, Parker JL, Lugus JJ, Walsh K. Adipokines in inflammation and metabolic disease. Nat Rev Immunol 2011; 11(2): 85-97.

47. Hebbard L, Ranscht B. Multifaceted roles of adiponectin in cancer. Best Pract Res Clin Endocrinol Metab 2014; 28(1): 59-69.

48. Panis C, Herrera AC, Aranome AM, et al. Clinical insights from adiponectin analysis in breast cancer patients reveal its anti-inflammatory properties in non-obese women. Mol Cell Endocrinol 2014; 382(1): 190-196.

49. Bruun JM, Lihn AS, Verdich C, et al. Regulation of adiponectin by adipose tissue-derived cytokines: in vivo and in vitro investigations in humans. Am J Physiol Endocrinol Metab 2003; 285: E527-E533.

50. Smitka K, Marešová D. Adipose Tissue as an Endocrine Organ: An Update on Pro-inflammatory and Anti-inflammatory Microenvironment. Prague Med Rep 2015; 116(2): 87-111.

51. Hursting SD, Dunlap SM. Obesity, metabolic dysregulation, and cancer: a growing concern and an inflammatory (and microenvironmental) issue. Ann NY Acad Sci 2012; 1271: 82-87.

52. Lafontan M. Adipose tissue and adipocyte dysregulation. Diabetes Metab 2014, 40(1): 16-28

53. Wood IS, de Heredia FP, Wang B, Trayhurn P. Cellular hypoxia and adipose tissue dysfunction in obesity. Proc Nutr Soc 2009; 68(4): 370-377.

54. de Ferranti S, Mozaffarian D. The perfect storm: obesity, adipocyte dysfunction, and metabolic consequences. Clin Chem 2008; 54(6): 945-955.
55. Sommer G, Kralisch S, Stangl V, et al. Secretory products from human adipocytes stimulate proinflammatory cytokine secretion from human endothelial cells. J Cell Biochem 2009; 106(4): 729-737.

56. Suganami T, Nishida J, Ogawa Y. A paracrine loop between adipocytes and macrophages aggravates inflammatory changes: role of free fatty acids and tumor necrosis factor alpha. Arterioscler Thromb Vasc Biol 2005; 25(10): 2062-2068.

57. Fasshauer M, Blüher M. Adipokines in health and disease. Trends Pharmacol Sci $2015 ; 36(7)$ : 461-470

58. Blüher M. Clinical relevance of adipokines. Diabetes Metab J 2012; 36(5): 317-327

59. Koerner A, Kratzsch J, Kiess W. Adipocytokines: leptin--the classical, resistin--the controversical, adiponectin--the promising, and more to come. Best Pract Res Clin Endocrinol Metab 2005; 19(4): 525-546.

60. Apostolopoulos V, de Courten MP, Stojanovska L, et al. The complex immunological and inflammatory network of adipose tissue in obesity. Mol Nutr Food Res 2015; doi: 10.1002/mnfr.201500272

61. Hutcheson J. Adipokines influence the inflammatory balance in autoimmunity. Cytokine 2015; 75(2): 272-279.

62. Walker GE, Marzullo P, Ricotti R, et al. The pathophysiology of abdominal adipose tissue depots in health and disease. Horm Mol Biol Clin Investig 2014; 19(1): 57-74

63. Badoud F, Perreault M, Zulyniak MA, Mutch DM. Molecular insights into the role of white adipose tissue in metabolically unhealthy normal weight and metabolically healthy obese individuals. FASEB J 2015; 29(3): 748-758.

64. Ghigliotti G, Barisione C, Garibaldi S, et al. Adipose tissue immune response: novel triggers and consequences for chronic inflammatory conditions. Inflammation 2014; 37(4): 1337-1353.

65. Proença AR, Sertié RA, Oliveira AC, et al. New concepts in white adipose tissue physiology. Braz J Med Biol Res 2014; 47(3): 192-205.

66. Singh $P$, Sharma $P$, Sahakyan KR, et al. Differential effects of leptin on adiponectin expression with weight gain versus obesity. Int J Obes (Lond) 2015; doi: 10.1038/ijo.2015.181.

67. Sun $Y$, Xun $\mathrm{K}$, Wang $\mathrm{C}$, et al. Adiponectin, an unlocking adipocytokine. Cardiovasc Ther 2009; 27(1): 59-75.

68. Kadowaki T, Yamauchi T, Kubota N, et al. Adiponectin and adiponectin receptors in insulin resistance, diabetes, and the metabolic syndrome. J Clin Invest 2006; 116(7): 1784-1792.

69. Turer AT, Scherer PE. Adiponectin: mechanistic insights and clinical implications. Diabetologia 2012; 55(9): 2319-2326.

70. Nigro E, Scudiero O, Monaco ML, et al. New insight into adiponectin role in obesity and obesity-related diseases. Biomed Res Int 2014; 2014:658913.

71. Riestra P, Gebreab SY, Xu R, et al. Gender-specific associations between ADIPOQ gene polymorphisms and adiponectin levels and obesity in the Jackson Heart Study cohort. BMC Med Genet 2015; 16(1): 65. doi: 10.1186/s12881-015-0214-x

72. Lai $\mathrm{H}$, Lin N, Xing Z, Weng H, Zhang H. Association between the level of circulating adiponectin and prediabetes: A meta-analysis. J Diabetes Investig 2015; 6(4): 416-429.

73. Mather KJ, Goldberg RB. Clinical use of adiponectin as a marker of metabolic dysregulation. Best Pract Res Clin Endocrinol Metab 2014; 28(1): 107-117.

74. Kishida K, Funahashi T, Shimomura I. Adiponectin as a routine clinical biomarker. Best Pract Res Clin Endocrinol Metab 2014; 28(1): 119-130.

75. Magkos F, Fabbrini E, Patterson BW, Eagon JC, Klein S. Portal vein and systemic adiponectin concentrations are closely linked with hepatic glucose and lipoprotein kinetics in extremely obese subjects. Metabolism 2011; 60(11): 1641-1648.

76. Thompson HJ, Sedlacek SM, Wolfe P, et al. Impact of Weight Loss on Plasma Leptin and Adiponectin in Overweight-to-Obese Post Menopausal Breast Cancer Survivors. Nutrients 2015; 7(7): 5156-5176.

77. Beg MS, Saleem S, Turer A, et al. A Prospective Analysis of Plasma Adiponectin and Risk of Incident Cancer: The Dallas Heart Study. J Natl Compr Canc Netw 2015; 13(7):873-878

78. Mauro L, Naimo GD, Ricchio E, et al. Cross-Talk between Adiponectin and GF-IR in Breast Cancer. Front Oncol 2015; 5: 157.

79. Khan S, Shukla S, Sinha S, Meeran SM. Role of adipokines and cytokines in obesity-associated breast cancer: therapeutic targets. Cytokine Growth Factor Rev 2013; 24(6): 503-513

80. Nigro E, Scudiero $\mathrm{O}$, Sarnataro $\mathrm{D}$, et al. Adiponectin affects lung epithelial A549 cell viability counteracting TNFa and IL-1ß toxicity through AdipoR1. Int J Biochem Cell Biol 2013; 45(6): 1145-1153.

81. Nakayama S, Miyoshi $Y$, Ishihara $H$, Noguchi S. Growth-inhibitory effect of adiponectin via adiponectin receptor 1 on human breast cancer cells through inhibition of S-phase entry without inducing apoptosis. Breast Cancer Res Treat 2008; 112(3): 405-410.

82. Körner A, Pazaitou-Panayiotou K, Kelesidis T, et al. Total and high-molecular-weight adiponectin in breast cancer: in vitro and in vivo studies. J Clin Endocrinol Metab 2007; 92(3): 1041-1048.

83. Bub JD, Miyazaki T, Iwamoto Y. Adiponectin as a growth inhibitor in prostate cancer cells. Biochem Biophys Res Commun 2006; 340(4): 1158-1166.

84. Chang CY, Chen MJ, Yang WS, et al. Hypoadiponectinemia: a useful marker of dyslipidemia in women with polycystic ovary syndrome. Taiwan J Obstet Gynecol 2012; 51(4): 583-590. 
85. Guo XH, Wang JY, Gao Y, et al. Decreased adiponectin level is associated with aggressive phenotype of tongue squamous cell carcinoma. Cancer Sci 2013; 104(2): 206-213.

86. Kamada Y, Matsumoto H, Tamura S, et al. Hypoadiponectinemia accelerates hepatic tumor formation in a nonalcoholic steatohepatitis mouse model. J Hepatol 2007; 47(4): 556-564.

87. Lu JP, Hou ZF, Duivenvoorden WC, et al. Adiponectin inhibits oxidative stress in human prostate carcinoma cells. Prostate Cancer Prostatic Dis 2012; 15(1): 28-35

88. Dubois V, Delort L, Billard H, et al. Breast cancer and obesity: in vitro interferences between adipokines and proangiogenic features and/or antitumor therapies? PLoS One 2013; 8(3): e58541.

89. Hillon P, Guiu B, Vincent J, Petit JM. Obesity, type 2 diabetes and risk of digestive cancer. Gastroenterol Clin Biol 2010; 34(10): 529-533.

90. Panis C, Herrera AC, Aranome AM, et al. Clinical insights from adiponectin analysis in breast cancer patients reveal its anti-inflammatory properties in non-obese women. Mol Cell Endocrinol 2014; 382(1): 190-196.

91. Medina EA, Oberheu K, Polusani SR, et al. PKA/AMPK signaling in relation to adiponectin's antiproliferative effect on multiple myeloma cells. Leukemia 2014; 28(10): 2080-2089.

92. Hebbard L, Ranscht B. Multifaceted roles of adiponectin in cancer. Best Pract Res Clin Endocrinol Metab 2014; 28(1): 59-69.

93. He Y, Lu L, Wei X, et al. The multimerization and secretion of adiponectin are regulated by TNF-alpha. Endocrine 2015; DOI 10.1007/s12020-015-0741-4, pp $1-13$

94. Nagaraju GP, Aliya S, Alese OB. Role of adiponectin in obesity related gastrointestinal carcinogenesis. Cytokine Growth Factor Rev 2015; 26(1): 83-93.

95. Słomian G, Świętochowska E, Malinowska-Borowska J, et al. Association between chemotherapy and plasma adipokines in patients with colorectal cancer. Pharmacol Rep 2014; 66(5): 902-907.

96. Gulcelik MA, Colakoglu K, Dincer $\mathrm{H}$, et al. Associations between adiponectin and two different cancers: breast and colon. Asian Pac J Cancer Prev 2012; 13(1): 395-398

97. Otokozawa S, Tanaka R, Akasaka $\mathrm{H}$, et al. Associations of Serum Isoflavone, Adiponectin and Insulin Levels with Risk for Epithelial Ovarian Cancer: Results of a Case-control Study. Asian Pac J Cancer Prev 2015; 16(12): 4987-4991.

98. Zhang L, Wen K, Han X, et al. Adiponectin mediates antiproliferative and apoptotic responses in endometrial carcinoma by the AdipoRs/AMPK pathway. Gynecol Oncol 2015; 137(2): 311-320.

99. Long E, Beales IL. The role of obesity in oesophageal cancer development. Therap Adv Gastroenterol 2014; 7(6): 247-268.

100. Abe Vicente M, Donizetti Silva T, Barão K, et al. The influence of nutritional status and disease on adiponectin and TNF-a levels in colorectal cancer patients. Nutr Hosp 2014; 30(1): 140-146.

101. Huang B, Cheng X, Wang D, et al. Adiponectin promotes pancreatic cancer progression by inhibiting apoptosis via the activation of AMPK/Sirt1/PGC-1a signaling. Oncotarget 2014; 5(13): 4732-4745.

102. Nalabolu MR, Palasamudram K, Jamil K. Adiponectin and leptin molecular actions and clinical significance in breast cancer. Int J Hematol Oncol Stem Cell Res 2014; 8(1): 31-40.

103. Surmacz E. Leptin and adiponectin: emerging therapeutic targets in breast cancer. J Mammary Gland Biol Neoplasia 2013; 18(3-4): 321-332.

104. Friedman JM,Halaas JL. Leptin and the regulation of body weight in mammals. Nature 1998; 395: 763-770.

105. Münzberg H, Morrison CD. Structure, production and signaling of leptin. Metabolism 2015; 64(1): 13-23.

106. Farooqi IS, O'Rahilly S. 20 years of leptin: human disorders of leptin action. J Endocrinol 2014; 223(1): T63-70.

107. Allison MB, Myers MG Jr. 20 years of leptin: connecting leptin signaling to biological function. J Endocrinol 2014; 223(1): T25-35.

108. Crujeiras AB, Carreira MC, Cabia B, et al. Leptin resistance in obesity: An epigenetic landscape. Life Sci 2015; pii: S0024-3205(15)00259-3.

109. Sáinz N, Barrenetxe J, Moreno-Aliaga MJ, Martínez JA. Leptin resistance and diet-induced obesity: central and peripheral actions of leptin. Metabolism 2015; 64(1): 35-46.

110. Tilg H, Moschen AR. Mechanisms behind the link between obesity and gastrointestinal cancers. Best Pract Res Clin Gastroenterol 2014; 28(4): 599-610.

111. Andò S, Barone I, Giordano C, et al. The Multifaceted Mechanism of Leptin Signaling within Tumor Microenvironment in Driving Breast Cancer Growth and Progression. Front Oncol 2014; 4:340.

112. Delort L, Rossary A, Farges MC, et al. Leptin, adipocytes and breast cancer: Focus on inflammation and anti-tumor immunity. Life Sci 2015; pii: S0024-3205(15)00232-5.

113. Grossmann ME, Mizuno NK, Bonorden MJ, et al. Role of the adiponectin leptin ratio in prostate cancer. Oncol Res 2009; 18: 269-277.

114. Lang K, Ratke J. Leptin and Adiponectin: new players in the field of tumor cell and leukocyte migration. Cell Commun Signal 2009; 7: 27.

115. Nalabolu MR, Palasamudram K, Jamil K. Adiponectin and leptin molecular actions and clinical significance in breast cancer. Int J Hematol Oncol Stem Cell Res 2014; 8(1): 31-40.

116. Sharma D, Saxena NK, Vertino PM, Anania FA. Leptin promotes the proliferative response and invasiveness in human endometrial cancer cells by activating multiple signal-transduction pathways. Endocr Relat Cancer 2006; 13: 629-640
117. Choi JH, Park SH, Leung PC, Choi KC. Expression of leptin receptors and potential effects of leptin on the cell growth and activation of mitogen-activated protein kinases in ovarian cancer cells. J Clin Endocrinol Metab 2005; 90: 207-210.

118. Olefsky JM, Glass CK. Macrophages, inflammation, and insulin resistance. Annu Rev Physiol 2010; 72: 219-246.

119. Booth A, Magnuson A, Fouts J, Foster M. Adipose tissue, obesity and adipokines: role in cancer promotion. Horm Mol Biol Clin Investig 2015; 21(1): 57-74

120. Riondino S, Roselli M, Palmirotta R, et al. Obesity and colorectal cancer: role of adipokines in tumor initiation and progression. World J Gastroenterol 2014; 20(18): 5177-5190.

121. Howe LR, Subbaramaiah K, Hudis CA, Dannenberg AJ. Molecular pathways: adipose inflammation as a mediator of obesity-associated cancer. Clin Cancer Res 2013; 19(22): 6074-6083.

122. Pucino V, De Rosa V, Procaccini C, Matarese G. Regulatory T cells, leptin and angiogenesis. Chem Immunol Allergy 2014; 99: 155-169.

123. Iyengar NM, Hudis CA, Dannenberg AJ. Obesity and cancer: local and systemic mechanisms. Annu Rev Med 2015; 66: 297-309.

124. Lashinger LM, Ford NA, Hursting SD. Interacting inflammatory and growth factor signals underlie the obesity-cancer link. J Nutr 2014; 144(2): 109-113.

125. Rutkowski JM, Davis KE, Scherer PE. Mechanisms of obesity and related pathologies: the macro- and microcirculation of adipose tissue. FEBS J 2009; 276(20): 5738-5746.

126. Matafome P, Santos-Silva D, Sena CM, Seiça R. Common mechanisms of dysfunctional adipose tissue and obesity-related cancers. Diabetes Metab Res Rev 2013; 29(4):285-295.

127. Apostolopoulos V, de Courten MP, Stojanovska L, et al. The complex immunological and inflammatory network of adipose tissue in obesity. Mol Nutr Food Res 2015; doi: 10.1002/mnfr.201500272.

128. Wensveen FM, Valentić S, Šestan M, et al. The "Big Bang" in obese fat: Events initiating obesity-induced adipose tissue inflammation. Eur J Immunol 2015; 45(9): 2446-2456. doi: 10.1002/eji.201545502.

129. Lee BC, Lee J. Cellular and molecular players in adipose tissue inflammation in the development of obesity-induced insulin resistance. Biochim Biophys Acta $2014 ; 1842(3): 446-462$

130. Huh JY, Park YJ, Ham M, Kim JB. Crosstalk between adipocytes and immune cells in adipose tissue inflammation and metabolic dysregulation in obesity. Mol Cells 2014; 37(5): 365-371.

131. Seijkens T, Kusters P, Chatzigeorgiou A, et al. Immune cell crosstalk in obesity: a key role for costimulation? Diabetes 2014; 63(12): 3982-3991.

132. Park J, Morley TS, Kim M, et al. Obesity and cancer-mechanisms underlying tumour progression and recurrence. Nat Rev Endocrinol 2014; 10(8): 455-465.

133. Rogers CI, Prabhu KS, Vijay-Kumar M. The microbiome and obesity-an established risk for certain types of cancer. Cancer J 2014; 20(3): 176-180.

134. Lashinger LM, Ford NA, Hursting SD. Interacting inflammatory and growth factor signals underlie the obesity-cancer link. J Nutr 2014; 144(2): 109-113.

135. De Pergola G, Silvestris F. Obesity as a major risk factor for cancer. J Obes 2013; 2013:291546.

136. Heidland A, Klassen A, Rutkowski P, Bahner U. The contribution of Rudolf Virchow to the concept of inflammation: what is still of importance? J Nephrol 2006; 19 Suppl 10:S102-S109.

137. Schmidt A, Weber OF. In memoriam of Rudolf Virchow: a historical retrospective including aspects of inflammation, infection and neoplasia. Contrib Microbiol 2006; 13: 1-15.

138. McDonald LT, Russell DL, Kelly RR, et al. Hematopoietic stem cell-derived cancer-associated fibroblasts are novel contributors to the pro-tumorigenic microenvironment. Neoplasia 2015; 17(5):434-48.

139. Vona-Davis L, Gibson LF. Adipocytes as a critical component of the tumor microenvironment. Leuk Res 2013; 37(5): 483-484

140. Coppack SW. Pro-inflammatory cytokines and adipose tissue. Proc Nutr Soc 2001 Aug; 60(3): 349-56

141. Fain JN. Release of interleukins and other inflammatory cytokines by human adipose tissue is enhanced in obesity and primarily due to the nonfat cells. Vitam Horm 2006; 74: 443-477.

142. Trayhurn P, Wood IS. Adipokines: inflammation and the pleiotropic role of white adipose tissue. Br J Nutr 2004; 92(3): 347-55.

143. Trayhurn P, Wang B, Wood IS. Hypoxia and the endocrine and signalling role of white adipose tissue. Arch Physiol Biochem 2008; 114(4): 267-276.

144. Tzanavari T, Giannogonas P, Karalis KP. TNF- $\alpha$ and obesity. Current Directions in Autoimmunity 2010; 11: 145- 156.

145. Wang X, Lin Y. Tumor necrosis factor and cancer, buddies or foes? Acta Pharmacologica Sinica 2008; 29(11): 1275- 1288.

146. Ungefroren H, Gieseler F, Fliedner S, Lehnert H. Obesity and cancer. Horm Mol Biol Clin Investig 2015; 21(1): 5-15.

147. Jain SS, Bird RP. Elevated expression of tumor necrosis factor-alpha signaling molecules in colonic tumors of Zucker obese (fa/fa) rats. Int J Cancer 2010; 127: 2042-2050.

148. Chen YL, Yan MY, Chien SY, et al. Sann-Joong-Kuey-Jian-Tang inhibits hepatocellular carcinoma Hep-G2 cell proliferation by increasing TNF-a, Caspase- 8 , Caspase- 3 and Bax but by decreasing TCTP and Mcl-1 expression in vitro. Mol Med Rep 2013; 7(5): 1487-1493.

149. Lukasiak S, Schiller C, Oehlschlaeger P, et al. Proinflammatory cytokines cause FAT10 upregulation in cancers of liver and colon. Oncogene 2008; 27(46): 6068-6074. 
150. Schwartz B, Yehuda-Shnaidman E. Putative role of adipose tissue in growth and metabolism of colon cancer cells. Front Oncol 2014; 4:164

151. Pérez-Hernández AI, Catalán V, Gómez-Ambrosi J, et al. Mechanisms linking excess adiposity and carcinogenesis promotion. Front Endocrinol (Lausanne) 2014; 5:65.

152. Kern PA, Ranganathan S, Li C, et al. Adipose tissue tumor necrosis factor and interleukin-6 expression in human obesity and insulin resistance. Am J Physiol Endocrinol Metab 2001; 280: E745-751.

153. Kim JH, Bachmann RA, Chen J. Interleukin-6 and insulin resistance. Vitamins \& Hormones 2009; 80: 613-633.

154. Park HS, Park JY, Yu R. Relationship of obesity and visceral adiposity with serum concentrations of CRP, TNF- $\alpha$ and IL-6. Diabetes Research and Clinical Practice 2005; 69(1): 29-35.

155. Syed V, Ulinski G, Mok SC, Ho SM. Reproductive hormone-induced, STAT3-mediated interleukin 6 action in normal and malignant human ovarian surface epithelial cells. Journal of the National Cancer Institute 2002; 94(8): 617- 629 .

156. Sriuranpong V, Park JI, Amornphimoltham P, et al. Epidermal growth factor receptor-independent constitutive activation of STAT3 in head and neck squamous cell carcinoma is mediated by the autocrine/paracrine stimulation of the interleukin 6/gp130 cytokine system. Cancer Research 2003; 63(11): 2948- 2956

157. Giri D, Ozen M, Ittmann M. Interleukin-6 is an autocrine growth factor in human prostate cancer. American Journal of Pathology 2001; 159(6): 2159-2165.

158. Li YY, Hsieh LL, Tang RP, et al. Interleukin-6 (IL-6) released by macrophages induces IL-6 secretion in the human colon cancer HT-29 cell line. Human Immunology 2009; 70(3): 151-158

159. Pei BX, Sun BS, Zhang ZF, et al. Interstitial tumor-associated macrophages combined with tumor-derived colony-stimulating factor- 1 and interleukin-6, a novel prognostic biomarker in non-small cell lung cancer. J Thorac Cardiovasc Surg 2014; 148(4): 1208-1216.e2.

160. Chen ZY, Raghav K, Lieu CH, et al. Cytokine profile and prognostic significance of high neutrophil-lymphocyte ratio in colorectal cancer. Br J Cancer 2015; 112(6): 1088-1097.

161. Tripsianis G, Papadopoulou E, Anagnostopoulos K, et al. Coexpression of IL-6 and TNF-a: prognostic significance on breast cancer outcome. Neoplasma 2014; 61(2): 205-212.

162. Juretić M, Cerović R, Belušić-Gobić M, et al. Salivary levels of TNF-a and IL-6 in patients with oral premalignant and malignant lesions. Folia Biol (Praha) 2013; 59(2): 99-102

163. Wolf JS, Chen Z, Dong G, et al. IL (interleukin)-1 alpha promotes nuclear factor-kappaB and AP-1-induced IL-8 expression, cell survival, and proliferation in head and neck squamous cell carcinomas. Clin Cancer Res 2001; 7(6): 1812-1820.

164. Jung YJ, Isaacs JS, Lee S, et al. IL-1beta-mediated up-regulation of HIF-1alpha via an NFkappaB/COX-2 pathway identifies HIF-1 as a critical link between inflammation and oncogenesis. FASEB J 2003; 17(14): 2115-2117.

165. van de Woestijne AP, Monajemi H, Kalkhoven E, Visseren FL. Adipose tissue dysfunction and hypertriglyceridemia: mechanisms and management. Obes Rev 2011; 12(10): 829-840.

166. Coppack SW. Pro-inflammatory cytokines and adipose tissue. Proc Nutr Soc 2001; 60(3): 349-356

167. Vergès B. Lipid modification in type 2 diabetes: the role of LDL and HDL. Fundam Clin Pharmacol 2009; 23(6): 681-685.

168. Soares FL, de Oliveira Matoso R, Teixeira LG, et al. Gluten-free diet reduces adiposity, inflammation and insulin resistance associated with the induction of PPAR-alpha and PPAR-gamma expression. J Nutr Biochem 2013; 24(6): 1105-1111.

169. Takahashi M, Hiyama Y, Yokoyama M, et al. In vivo arterial lipoprotein lipase expression augments inflammatory responses and impairs vascular dilatation. Arterioscler Thromb Vasc Biol 2008; 28(3): 455-462.

170. Wang L, Gill R, Pedersen TL, et al. Triglyceride-rich lipoprotein lipolysis releases neutral and oxidized FFAs that induce endothelial cell inflammation. J Lipid Res 2009; 50(2): 204-213.

171. Goodwin PJ, Ennis M, Pritchard KI, et al. Fasting insulin and outcome in early-stage breast cancer: results of a prospective cohort study. J Clin Oncol 2002; 20: 42-51.

172. Ma J, Li H, Giovannucci E, et al. Prediagnostic body-mass index, plasma C-peptide concentration and prostate cancer-specific mortality in men with prostate cancer: a long-term survival analysis. Lancet Oncol 2008; 9: 1039-1047.

173. Barone BB, Yeh HC, Snyder CF, et al. Long-term all-cause mortality in cancer patients with preexisting diabetes mellitus: a systematic review and meta-analysis. JAMA 2008; 300: 2754-2764.

174. Wood IS, de Heredia FP, Wang B, Trayhurn P. Cellular hypoxia and adipose tissue dysfunction in obesity. Proc Nutr Soc 2009; 68(4): 370-377.

175. Suganami T, Nishida J, Ogawa Y. A paracrine loop between adipocytes and macrophages aggravates inflammatory changes: role of free fatty acids and tumor necrosis factor alpha. Arterioscler Thromb Vasc Biol 2005; 25(10): 2062-2068.

176. Kohlgruber A, Lynch L. Adipose Tissue Inflammation in the Pathogenesis of Type2 Diabetes. Curr Diab Rep 2015; 15(11): 92.
177. Subramanian M, Ozcan L, Ghorpade DS, et al. Suppression of Adaptive Immune Cell Activation Does Not Alter Innate Immune Adipose Inflammation or Insulin Resistance in Obesity. PLoS One 2015; 10(8):e0135842.

178. Zhao $\mathrm{L}, \mathrm{Fu} \mathrm{Z}, \mathrm{Wu} \mathrm{J}$, et al. Inflammation-induced microvascular insulin resistance is an early event in diet-induced obesity. Clin Sci (Lond) 2015; 129(12): 1025-1036.

179. Pedersen DJ, Guilherme A, Danai LV et al. A major role of insulin in promoting obesity-associated adipose tissue inflammation. Mol Metab 2015; 4(7): 507-518.

180. Chen L, Chen R, Wang H, Liang F. Mechanisms Linking Inflammation to Insulin Resistance. Int J Endocrinol 2015; 2015:508409 doi: $10.1155 / 2015 / 508409$

181. Wieser V, Moschen AR, Tilg H. Inflammation, cytokines and insulin resistance: a clinical perspective. Arch Immunol Ther Exp (Warsz) 2013; 61(2): 119-125.

182. Barbarroja N, Lopez-Pedrera C, Garrido-Sanchez L, et al. Progression from high insulin resistance to type 2 diabetes does not entail additional visceral adipose tissue inflammation. PLoS One 2012; 7(10): e48155.

183. Barbarroja N, López-Pedrera R, Mayas MD, et al. The obese healthy paradox: is inflammation the answer? Biochem J 2010; 430(1): 141-149.

184. Hu Y, Deng F, Song J, et al. Evaluation of miR-29c inhibits endotheliocyte migration and angiogenesis of human endothelial cells by suppressing the insulin like growth factor 1. Am J Transl Res 2015; 7(5): 866-877.

185. Brahmkhatri VP, Prasanna C, Atreya HS. Insulin-like growth factor system in cancer: novel targeted therapies. Biomed Res Int 2015; 2015:538019.

186. Liu Q, Xu Z, Mao S, et al. Effect of hypoxia on hypoxia inducible factor-1a, insulin-like growth factor I and vascular endothelial growth factor expression in hepatocellular carcinoma HepG2 cells. Oncol Lett 2015; 9(3): 1142-1148.

187. Ma W, Zhang T, Pan J, et al. Assessment of insulin-like growth factor 1 receptor as an oncogene in esophageal squamous cell carcinoma and its potential implication in chemotherapy. Oncol Rep 2014; 32(4): 1601-1609.

188. Wood IS, de Heredia FP, Wang B, Trayhurn P. Cellular hypoxia and adipose tissue dysfunction in obesity. Proc Nutr Soc 2009; 68(4): 370-377.

189. Trayhurn P, Wang B, Wood IS. Hypoxia in adipose tissue: a basis for the dysregulation of tissue function in obesity? Br J Nutr 2008; 100(2): 227-235.

190. Kang YS. Obesity associated hypertension: new insights into mechanism. Electrolyte Blood Press 2013; 11(2): 46-52.

191. Lafontan M. Adipose tissue and adipocyte dysregulation. Diabetes Metab 2014; 40(1): 16-28.

192. Algire C, Medrikova D, Herzig S. White and brown adipose stem cells: from signaling to clinical implications. Biochim Biophys Acta 2013; 1831(5): 896-904.

193. Murdolo G, Piroddi M, Luchetti F, et al. Oxidative stress and lipid peroxidation by-products at the crossroad between adipose organ dysregulation and obesity-linked insulin resistance. Biochimie 2013; 95(3): 585-594.

194. Sansbury BE, Cummins TD, Tang Y, et al. Overexpression of endothelial nitric oxide synthase prevents diet-induced obesity and regulates adipocyte phenotype. Circ Res 2012; 111(9): 1176-1189.

195. Fredriksson JM, Nikami H, Nedergaard J. Cold-induced expression of the VEGF gene in brown adipose tissue is independent of thermogenic oxygen consumption. FEBS Lett 2005; 579(25): 5680-5684

196. Shimizu I, Aprahamian T, Kikuchi R, et al. Vascular rarefaction mediates whitening of brown fat in obesity. J Clin Invest 2014; 124(5): 2099-2112.

197. Bhattacharya I, Domínguez AP, Drägert K, et al. Hypoxia potentiates tumor necrosis factor- $\alpha$ induced expression of inducible nitric oxide synthase and cyclooxygenase- 2 in white and brown adipocytes. Biochem Biophys Res Commun. 2015 May 29;461(2):287-92.

198. Vernochet C, Damilano F, Mourier A, et al. Adipose tissue mitochondrial dysfunction triggers a lipodystrophic syndrome with insulin resistance, hepatosteatosis, and cardiovascular complications. FASEB J 2014; 28(10): 4408-4419.

199. Trayhurn P, Alomar SY. Oxygen deprivation and the cellular response to hypoxia in adipocytes - perspectives on white and brown adipose tissues in obesity. Front Endocrinol (Lausanne) 2015; 6:19. doi: 10.3389/fendo.2015.00019. eCollection 2015.

200. Trayhurn P. Hypoxia and adipocyte physiology: implications for adipose tissue dysfunction in obesity. Annu Rev Nutr 2014; 34: 207-236.

201. Netzer N, Gatterer H, Faulhaber M, et al. Hypoxia, Oxidative Stress and Fat. Biomolecules 2015; 5(2): 1143-1150.

202. Closa D, Folch-Puy E. Oxygen free radicals and the systemic inflammatory response. IUBMB Life 2004; 56(4): 185-191.

203. Belarbi Y, Mejhert N, Lorente-Cebrián S, et al. MicroRNA-193b Controls Adiponectin Production in Human White Adipose Tissue. J Clin Endocrinol Metab 2015; 100(8): E1084-1088.

204. Omatsu-Kanbe M, Matsuura H. Novel intracellular mediator of adiponectin secretion from adipocytes. J Physiol 2014; 592(Pt 23): 5141

205. Cao Y. Angiogenesis and vascular functions in modulation of obesity, adipose metabolism, and insulin sensitivity. Cell Metab 2013; 18(4): 478-489.

206. Marnett LJ. Oxyradicals and DNA damage. Carcinogenesis 2000; 21(3): 361-370.

207. Klaunig JE, Kamendulis LM, Hocevar BA. Oxidative stress and oxidative damage in carcinogenesis. Toxicol Pathol 2010; 38(1): 96-109.

208. Hwang ES, Bowen PE. DNA damage, a biomarker of carcinogenesis: its measurement and modulation by diet and environment. Crit Rev Food Sci Nutr 2007; 47(1): 27-50. 
209. Sears B, Perry M. The role of fatty acids in insulin resistance. Lipids Health Dis 2015; 14(1): 121. doi: 10.1186/s12944-015-0123-1

210. Derosa G, Fogari E, D'Angelo A, et al. Adipocytokine levels in obese and non-obese subjects: an observational study. Inflammation 2013; 36(4): 914-920.

211. Matafome P, Santos-Silva D, Sena CM, Seiça R. Common mechanisms of dysfunctional adipose tissue and obesity-related cancers. Diabetes Metab Res Rev 2013; 29(4): 285-295.

212. Sethi JK, Vidal-Piug AJ. Adipose tissue function and plasticity orchestrate nutritional adaptation. J Lipid Res 2007; 48: 1253-1262.

213. Gregoire FM, Smas CM, Sul HS. Understanding adipocyte differentiation. Physiol Rev 1998; 78: 783-809.

214. Ruan H, Zarnowski MJ, Cushman SW, Lodish HF. Standard isolation of primary adipose cells from mouse epididymal fat pads induces inflammatory mediators and down-regulates adipocyte genes. J Biol Chem 2003; 278 (48): $47585-47593$.

215. Schwartz B, Yehuda-Shnaidman E. Putative role of adipose tissue in growth and metabolism of colon cancer cells. Front Oncol 2014; 4: 164

216. Nieman KM, Kenny HA, Penicka CV, et al. Adipocytes promote ovarian cancer metastasis and provide energy for rapid tumor growth. Nat Med 2011; 17(11): 1498-1503.

217. Zhang Y, Nowicka A, Solley TN, et al. Stromal Cells Derived from Visceral and Obese Adipose Tissue Promote Growth of Ovarian Cancers. PLoS One 2015; 10(8): e0136361.

218. Jung YY, Lee YK, Koo JS. Expression of cancer-associated fibroblast-related proteins in adipose stroma of breast cancer. Tumour Biol 2015; 36(11): 8685-95.

219. Booth A, Magnuson A, Fouts J, Foster M. Adipose tissue, obesity and adipokines: role in cancer promotion. Horm Mol Biol Clin Investig 2015; 21(1): 57-74

220. Park EJ, Lee JH, Yu GY, et al. Dietary and genetic obesity promote liver inflammation and tumor genesis by enhancing IL- 6 and TNF expression. Cell 2010; 140(2): 197-208 